\title{
ECONOMIC VALUE ADDED DAN MARKET VALUE ADDED SERTA PERILAKU HARGA SAHAM PERUSAHAAN YANG LISTING DI JAKARTA ISLAMIC INDEX \\ (Periode 2010-2014)1)
}

\author{
Khairuriza \\ Program Studi S1 Ekonomi Islam-Fakultas Ekonomi dan Bisnis-Universitas Airlangga \\ Email: dlighter59@gmail.com \\ Leo Herlambang \\ Departemen Ekonomi Syariah-Fakultas Ekonomi dan Bisnis-Universitas Airlangga \\ Email: leo.herlambang@gmail.com
}

\begin{abstract}
:
Stern Stewart \& Co. introduced new methods of measuring financial performance based on the added value produced by the company, these methods being Economic Value Added (EVA) and Market Value Added (MVA). The purpose of this research is to analyze the effect of EVA and MVA toward the stock price of companies listed in Jakarta Islamic Index (JII) for the year period 2010-2014.

The data used in this research are secondary data comprising of yearly data for the period 2010-2014. The analysis employed in this research is through using multiple linear regression analysis with a of 0.05 .

the research suggest that EVA and MVA partially and simultaneously have significance effect towards the stock price of the company enlisted in JII. With a of 0.162 or $16.2 \%$, this shows that 16, 2\% of stock price in JII is affected by EVA and MVA, whereas $83,8 \%$ is affected by other variables.

Keywords: Stock Price. Jakarta Islamic Index, Economic Value Added (EVA), dan Market Value Added (MVA).
\end{abstract}

\section{PENDAHULUAN}

Islam adalah agama yang sempurna dan universal. Etika berlaku untuk setiap aspek kehidupan umat Islam. Beruntungnya, dalam Islam pertanyaan tentang apakah suatu tindakan dianggap kebijakan atau keburukan ditentukan dalam Al-Qur'an dan Sunnah (Hadist), yang secara harfiah berarti cara hidup Nabi, yang sebagian berasal dari ucapan dan tindakannya. Allah swt berfirman di dalam Alquran:

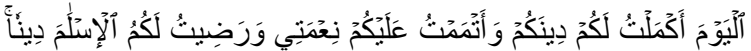

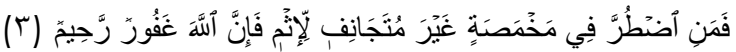

"Pada hari ini telah Kusempurnakan untuk kamu agamamu, dan telah Kucukupkan kepadamu nikmat-Ku, dan telah Ku-ridhai Islam itu Jadi agama bagimu. Maka barang siapa terpaksa karena kelaparan tanpa sengaja berbuat dosa, Sesungguhnya Allah Maha Pengampun lagi Maha Penyayang." (Al-Maidah : 3)

Islam mampu menjamin tercapainya kemakmuran hidup manusia dalam segala bidang, termasuk kesejahteraan ekonomi.Dalam bidang ekonomi khususnya, Islam juga telah mengaturnya dan mengkonsepnya dengan sangat komprehensif. Yang mana berekonomi adalah termasuk dalam muamalah, dan dalam bermuamalah segala sesuatunya diperbolehkan, kecuali yang dilarang oleh Allah dan Rasul-Nya dengan kerangka Islam.

Pemberdayaan ekonomi umat dapat dilakukan dengan berbagai cara. Salah

\footnotetext{
1) Jurnal ini merupakan bagian dari skripsi dari Khairuriza, NIM : 041114060 , yang diuji pada 1 Februari 2016
} 
Khairuriza, et al/Jurnal Ekonomi Syariah Teori dan Terapan Vol. 3 No. 6 Juni 2016: 444-459; ECONOMIC VALUE ADDED DAN MARKET VALUE ADDED SERTA PERILAKU HARGA SAHAM PERUSAHAAN YANG LISTING DI JAKARTA ISLAMIC INDEX (Periode 2010-2014)

satunya adalah melakukan investasi. Problematika kesejahteraan ekonomi yang terjadi pada kehidupan manusia dapat sedikit terurai melalui adanya investasi. Investasi merupakan solusi atas permasalahan yang timbul akibat tidak terdistribusinya harta secara merata. Banyak cara yang dapat dilakukan untuk berinvestasi, salah satunya melakukan investasi di sektor saham. Saham sendiri berasal dari bahasa sahmun yang artinya andil atau peran serta dalam berserikat. Sementara menurut istilah, saham adalah satuan nilai atau pembukuan dalam berbagai instrumen finansial yang mengacu pada bagian kepemilikan sebuah perusahaan (Suryomurti, 2011:126)

Adanya fatwa-fatwa Dewan Syariah Nasional Indonesia No. 40/DSN-MUI/2003 juga memutuskan akan bolehnya jual beli saham. Terkait saham-saham yang bisa di beli insvestor terdapat dalam Jakarta Islamic Index yang dilakukan evaluasi setiah enam bulan sekali yaitu periode Januari-Juni dan Juli Desember yang jumlah emitennya ada 30 (Huda, 2010:68)

Pasar Modal sangat berperan bagi pembangunan ekonomi yaitu sebagai salah satu sumber pembiayaan eksternal bagi dunia usaha dan wahana investasi masyarakat. Oleh sebab itu partisipasi masyarakat sangat di harapkan untuk ikut aktif dalam menggerakan perekonomian. Penyediaan dana sektor swasta untuk pembangunan cukup besar, sehingga perlu digalakkannya pengerahan dana masyarakat baik melalui peranan perbankan maupun pengembangan pasar modal. Pemodal yang ingin menginvestasikan uangnya di pasar modal dapat lewat pembelian saham atau sertifikat dana.

Langkah awal per kembangan transaksi saham syariah pada pasar modal Indonesia tercatat dengan hadirnya Indeks Syariah atau Jakarta Islamic Index (JII) pada bulan Juli tahun 2000. Walaupun masih terbilang baru dalam industri pasar modal Indonesia, namun bisa dilihat kinerja Jakarta Islamic Index cukup menjanjikan.

Dalam perdagangan efek khususnya saham, informasi memiliki peranan yang dominan dan krusial. Suad Husnan (1998) menyebutkan bahwa sebuah pasar modal dikategorikan efisien jika harga sekuritasnya telah mencerminkan semua informasi yang relevan. Semakin cepat informasi terefleksikan pada harga sekuritas maka pasar modal tersebut semakin efisien. Pasar modal di Indonesia termasuk kedalam pasar modal yang kondisi efisien bentuk lemah (Weak from efficiency) yaitu harga mencerminkan semua informasi yang ada pada catatan dimasa lalu (Tinneke, 2007:2).

Untuk menganalisa kinerja perusahaan-perusahaan tersebut, para investor cenderung menggunakan analisa rasio kevangan menggunakan informasi yang tertera pada laporan keuangan atau prospektus perusahaan tersebut. Ukuran dan metode yang digunakan para investor berbeda-beda tergantung pada bentuk perusahaan tersebut. Namun pada 
Khairuriza, et al/Jurnal Ekonomi Syariah Teori dan Terapan Vol. 3 No. 6 Juni 2016: 444-459; ECONOMIC VALUE ADDED DAN MARKET VALUE ADDED SERTA PERILAKU HARGA SAHAM PERUSAHAAN YANG LISTING DI JAKARTA ISLAMIC INDEX (Periode 2010-2014)

umumnya analisa tersebut dilakukan dengan menggunakan metode rasio likuiditas (current ratio, quick ratio), rasio profitabilitas (return on equity, return on asset, return on investment), dan rasio solvabilitas. Metode analisa tradisional ini memiliki beberapa kelemahan diantaranya adalah mengabaikan adanya biaya modal.

Sebenarnya para investor menginginkan kekayaan yang ia miliki atas suatu saham bertambah dari pada hanya sekedar tingkat pengembaliannya. Memaksimalkan kesejahteraan pemegang saham merupakan tujuan utama dari setiap perusahaan. Para investorpun akan lebih jeli dalam menilai performa finansial perusahaan yang pada akhirnya akan meningkatkan harga sahamnya di pasar modal. Pengukuran tradisional seperti disebutkan pada paragraf sebelumnya merupakan metode penilaian kinerja keuangan yang paling umum dipakai oleh perusahaan dan investor. Namun dalam beberapa waktu terakhir, metode pengukuran kinerja keuangan yang berdasarkan nilai telah mendapat banyak perhatian dari kalangan investor dan perusahaan. Ada beberapa metode pengukuran berdasarkan nilai salah satunya seperti Eonomic Value Added (EVA) dan Market Value Added (MVA).

Penelitian ini dibuat untuk mengetahui pengaruh valuasi saham syariah, yaitu dengan menggunakan Economic Value Added (EVA) dan Market Value Added (MVA), terhadap harga saham perusahaan-perusahaan yang terdaftar di Jakarta Islamic Index yang tercatat pada tahun 2014.

\section{LANDASAN TEORI}

Kinerja keuangan perusahaan adalah suatu usaha yang formal yang dilaksanakan perusahaan untuk mengevaluasi efesiensi dan efektivitas dari aktivitas perusahaan yang telah dilaksanakan pada periode tertentu. Pengukuran kinerja digunakan perusahaan untuk melakukan perbaikan atas kegiatan operasionalnya agar dapat bersaing dengan perusahaan lain.

Dalam Islam tujuan pelaporan keuangan adalah untuk memperkuat keyakinan, mengingat kan dan memelihara serta lebih memperkukuh kesaksian apabila timbul suatu pertanyaan atau permasalahan dalam suatu transaksi dikemudian hari. Damsyiki dalam Wahyudi (2009:38) mengatakan apabila muamalah secara tidak tunai atau utang piutang maka hendaklah diadakan pencatatan, karena dengan catatan akan lebih memelihara jumlah barang dan masa pembayarannya serta lebih tegas bagi orang yang menyaksikannya, namun perintah pencatatan dalam masalah ini mengandung arti petunjuk bukan wajib. Sebagaimana firman Allah dalam surat AlBaqarah ayat 282 yang berbunyi :

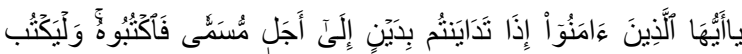

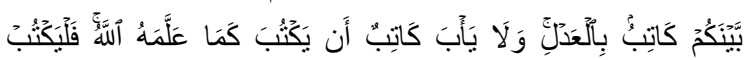

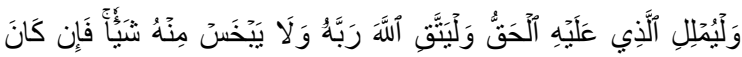

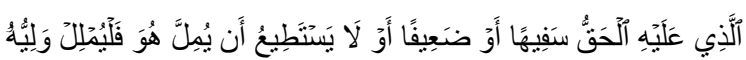




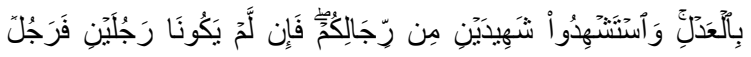

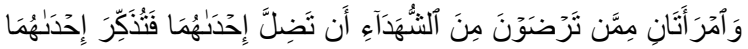

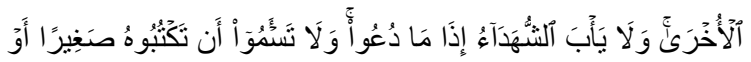

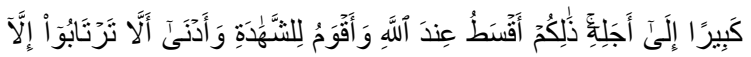

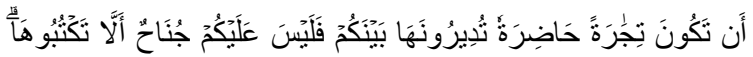

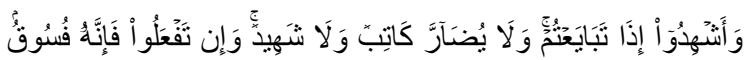

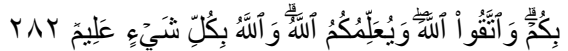

"Hai orang-orang yang beriman, apabila kamu bermu'amalah tidak secara tunai untuk waktu yang ditentukan, hendaklah kamu menuliskannya. dan hendaklah seorang penulis di antara kamu menuliskannya dengan benar. dan janganlah penulis enggan menuliskannya sebagaimana Allah mengajarkannya, meka hendaklah ia menulis, dan hendaklah orang yang berhutang itu mengimlakkan (apa yang akan ditulis itu), dan hendaklah ia bertakwa kepada Allah Tuhannya, dan janganlah ia mengurangi sedikitpun daripada hutangnya. jika yang berhutang itu orang yang lemah akalnya atau lemah (keadaannya) atau Dia sendiri tidak mampu mengimlakkan, Maka hendaklah walinya mengimlakkan dengan jujur. dan persaksikanlah dengan dua orang saksi dari orang-orang lelaki (di antaramu). jika tak ada dua oang lelaki, Maka (boleh) seorang lelaki dan dua orang perempuan dari saksi-saksi yang kamu ridhai, supaya jika seorang lupa Maka yang seorang mengingatkannya. janganlah saksisaksi itu enggan (memberi keterangan) apabila mereka dipanggil; dan janganlah kamu jemu menulis hutang itu, baik kecil maupun besar sampai batas waktu membayarnya. yang demikian itu, lebih adil di sisi Allah dan lebih menguatkan persaksian dan lebih dekat kepada tidak (menimbulkan) keraguanmu. (Tulislah mu'amalahmu itu), kecuali jika mu'amalah itu perdagangan tunai yang kamu jalankan di antara kamu, Maka tidak ada dosa bagi kamu, (jika) kamu tidak menulisnya. dan persaksikanlah apabila kamu berjual beli; dan janganlah penulis dan saksi saling sulit menyulitkan. jika kamu lakukan (yang demikian), Maka Sesungguhnya hal itu adalah suatu kefasikan pada dirimu. dan bertakwalah kepada Allah; Allah mengajarmu; dan Allah Maha mengetahui segala sesuatu." (AlBaqarah ; 182)

Islam menyatakan bahwa dalam setiap bisnis mutlak ada yang dinamakan nilai tambah, yang mana dengan nilai tambah tersebut diperoleh suatu keuntungan yang akan mampu memberikan secara adil hak-hak atau bagi hasil yang seharusnya diperoleh oleh para penyandang dana, dalam hal ini pemegang saham, selain itu dengan nilai tambah tersebut, perusahaan akan dapat meningkatkan kesejahteraan karyawan dan masyarakat sekitar perusahaan melalui zakat. Dalam hal ini Allah menjelaskan melalui firman-Nya dalam surat Ar-Ruum ayat 39 yang berbunyi :

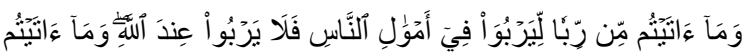

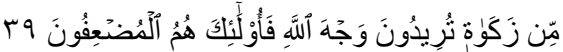

"Dan sesuatu Riba (tambahan) yang kamu berikan agar Dia bertambah pada harta manusia, Maka Riba itu tidak menambah pada sisi Allah. dan apa yang kamu berikan berupa zakat yang kamu maksudkan untuk mencapai keridhaan Allah, Maka (yang berbuat demikian) Itulah orangorang yang melipat gandakan (pahalanya)."(Ar-Rum : 39)

Istilah EVA pertama kali dipopulerkan oleh Stern Stewart Management Service yang merupakan perusahaan konsultan dari Amerika Serikat pada tahun 1980-an. EVA telah lama dikenal oleh para ekonom sebagai Economic Profit, yaitu nilai profit 
Khairuriza, et al/Jurnal Ekonomi Syariah Teori dan Terapan Vol. 3 No. 6 Juni 2016: 444-459; ECONOMIC VALUE ADDED DAN MARKET VALUE ADDED SERTA PERILAKU HARGA SAHAM PERUSAHAAN YANG LISTING DI JAKARTA ISLAMIC INDEX (Periode 2010-2014)

yang melebihi (kurang dari) tingkat pengembalian minimum yang bisa diperoleh (diderita) oleh pemegang saham dan kreditor dengan berinvestasi di sekuritas lain yang mempunyai risiko sebanding (opportunity cost) (Wahyudi, 2009:19) atau dapat diformulasikan sebagai berikut:

EVA $=$ NOPAT - Capital Charge

EVA relatif dapat dirumuskan sebagai berikut:

EVA relatif (re) $=\frac{\text { EVA }}{\text { Total Aktifa }} \times 100 \%$

Keterangan :

1. Jika EVA $>0$, maka terjadi proses nilai tambah perusahaan, sehingga menunjukkan kinerja keuangan perusahaan cukup baik.

2. Jika $E V A=0$, maka menunjukkan posisi impas perusahaan karena semua laba digunakan untuk membayar kewajiban kepada penyandang dana, baik investor maupun kereditor.

3. Jika EVA $<0$, maka total biaya modal perusahaan lebih besar daripada laba operasi setelah pajak sehingga kinerja keuangan perusahaan tersebut tidak baik.

Economic Value Added merupakan suatu konsep untuk mengukur penciptaan nilai perusahaan yang tidak bergantung pada metode akuntansi yang dipakai serta memeprhitungkan biaya modal. Bennet Stewart dan Joel M. Stern dalam Manna (2011) adalah seorang analis kevangan dari perusahaan Stern Stewart \& Co memperkenalkan salah satu cara menilai kinerja perusahaan yaitu Economic Value Added. Economic Value Added adalah alat ukur kinerja keuangan untuk memperhitungkan keuntungan ekonomis perusahaan sebenarnya. Economic Value Added dapat diperhitungkan dengan laba bersih setelah pajak dikurang biaya modal yang diinvestasikan. Economic Valve Added yang bernilai positif berarti perusahaan dianggap telah mampu menciptakan nilai bagi pemegang saham karena mampu menghasilkan laba operasi di atas biaya modal.

Keunggulan EVA menurut Teuku Mirza, 1997 (Octavia, 2012:15) yaitu "EVA memfokuskan penilaiannya pada nilai tambah dengan memperhatikan beban biaya modal sebagai konsekuensi investasi". Dengan diperhitingkannya biaya modal maka dapat diketahui apakah perusahaan dapat menciptakana nilai tambaha atau tidak. Kelebihan EVA yang lain adalah dapat digunakan secara mandiri tanpa memerlukan data pembanding

Selain memiliki keunggulan tersebut, EVA juga memiliki kelemahan. Menurut Dewi dalam Octavia (2012:15)

"EVA hanya menggambarkan penciptaan nilai pada suatu periode tahun tertentu. Padahal nilai perusahaan merupakan akumulasi EVA pada periode tertentu positif tetapi nilai perusahaan tersebut rendah karena nilai EVA dimasalalunya negatif."

Thenmozhi (2000) mendefinisikan "Market Valve Added is the difference between the Company's market and book value of shares." Artinya MVA 
Khairuriza, et al/Jurnal Ekonomi Syariah Teori dan Terapan Vol. 3 No. 6 Juni 2016: 444-459; ECONOMIC VALUE ADDED DAN MARKET VALUE ADDED SERTA PERILAKU HARGA SAHAM PERUSAHAAN YANG LISTING DI JAKARTA ISLAMIC INDEX (Periode 2010-2014)

adalah perbedaan antara nilai pasar perusahaan (termasuk ekuitas dan vang) dan modal keseluruhan yang diinvestasikan dalam perusahaan. Nilai pasar adalah nilai perusahaan. Yakni jumlah nilai pasar dari semua tuntutan modal terhadap perusahaan oleh pasar modal pada tanggal tertentu.

Menurut Brigham \& Houston (2011:111) MVA adalah perbedaan antara nilai pasar ekuitas suatu perusahaan dengan nilai buku seperti yang disajikan dalam neraca, nilai pasar dihitung dengan mengalikan harga saham dengan jumlah saham yang beredar. Sedangkan menurut Manurung dalam Rahayu (2013) MVA adalah perbedaan nantara nilai pasar dari perusahaan (hutang dan ekuitas) dengan total modal yang diinvestasikan ke dalam perusahaan. Nilai pasar dari perusahaan merupakan nilai perusahaan (enterprise value) dari perusahaan yang bersangkutan. Dimana nilai ini merupakan hasil jumlah seluruh nilai pasar yang diklaim oleh pihak lain terhadap perusahaan pada suatu waktu tertentu. Total modal yang diinvestasikan kedalam perusahaan adalah seluruh investasi yang dilakukan semua pihak kepada perusahaan pada suatu waktu tertentu.

Berdasarkan Steward, Thenmozhi (2000) merumuskan MVA sebagai berikut :

Market Value Added = Company's total Market Valve - Capital Invested
Dengan menyerderhanakan asumsi bahwa nilai pasar dan nilai buku terhadap hutang adalah sama, maka :

Market Value Added $=$ Market Value of Equity - Book Value of Equity

MVA yang positif berarti menunjukkan pihak manajemen telah mampu meningkatkan kekayaan pemegang saham dan MVA yang negatif mengakibatkan berkurangnya nilai modal pemegang saham, jika MVA sama dengan 0 maka perusahaan tidak mampu meningkatkan kekayaan bagi pemegang saham. Sehingga memaksimalkan nilai MVA seharusnya menjadi tujuan utama perusahaan dalam meningkatkan kekayaan pemegang saham (Zaky \& Ary dalam Wahyudi, 2009:33).

Dikutip dari Wahyudi (2009:34) menurut Zaky \& Ary, MVA merupakan ukuran tunggal dan dapat berdiri sendiri yang tidak membutuhkan analisis trend maupun norma industri sehingga bagi pihak manajemen dan penyedia dana akan lebih mudah dalam menilai kinerja perusahaan. Sedangkan kelemahan MVA adalah bahwa MVA hanya dapat diaplikasikan pada perusahaan yang sudah go public saja. Hal ini dikarenakan MVA dalam perhitungan MVA diperlukan jumlah serta harga saham dari perusahaan tersebut.

Jakarta Islamic Index adalah "indeks yang memperdagangkan saham - saham perusahaan pilihan dengan ketentuan antara lain operasinya tidak bertolak 
Khairuriza, et al/Jurnal Ekonomi Syariah Teori dan Terapan Vol. 3 No. 6 Juni 2016: 444-459; ECONOMIC VALUE ADDED DAN MARKET VALUE ADDED SERTA PERILAKU HARGA SAHAM PERUSAHAAN YANG LISTING DI JAKARTA ISLAMIC INDEX (Periode 2010-2014)

belakang dengan prinsip syariah Islam dan memiliki kinerja perusahaan yang baik" (Haruman dalam Octavia, 2012:28)

Berdasarkan arahan Dewan Pengawas Nasional dan peraturan Bapepam- LK nomor IX.A.13 tenttang penerbitan efek syariah, jenis kegiatan utama suatu badan usaha yang dinilai tidak memnuhi syariat Islam adalah:

1. Usaha perjudian dan permainan yang tergolong judi atau perdagangan yang dilarang.

2. Menyelenggarakan jasa keuangan yan bersifat ribawi, jual beli risiko yang mengandung gharar dan maysir.

3. Memproduksi, mendistribusikan, memperdagangkan dan atau menyediakan:

a. Barang dan jasa yang haram karena zatnya (haram li-dzatihi)

b. Barang atau jasa yang haram bukan karena zatnya (haram lighairi) dan yang ditetapkan oleh DSN-MUI

c. Barang dan jasa yang merusak moral dan bersifat mudarat.

4. Melakukan investasi pada perusahaan yang pada saat transaksi tingkat (nisbah) hutang perusahaan kepada lembaga keuangan ribawi lebih dominan dari modalnya, kecuali investasi tersebut dinyatakan kesyariahannya oleh DSN-MUI.

Sedangkan kriteria saham yang masuk dalam kategori syariah adalah :

1. Tidak melakukan kegiatan usaha sebagaimana yang dimaksud diatas.
2. Tidak melakukan perdagangan yang tidak disertai dengan penyerahan barang/jasa palsu

3. Tidak memiliki rasio keuangan sebagai berikut:

a. Total hutang yang berbasis bunga dibanding dengan modal ekuitas tidak melebihi $82 \%$ (hutang yang berbasis bunga dibandingkan dengan total ekuitas tidak lebih dari $45 \%: 55 \%$ )

b. Total pendapatan bunga dan pendapatan tidak halal lainya dibandingkan dengan total pendapatan (revenue) tidak lebih dari $10 \%$

Perusahaan yang sahamnya tercatat di Jakarta Islamic Index bersikap pasif. Artinya, mereka tidak mengupayakan agar saham perusahaannya masuk dalam JII, misalnya dengan menyesuaikan operasional bisnis mereka agar sesuai syariah. Sebaliknya JII lah yang aktif melakukan penyeleksian saham- saham yang tidak bertentangan dengan syariah.

Harga saham adalah harga yang terjadi paling akhir dalam satu hari bursa atau yang dapat disebut dengan harga penutupan. Harga saham terbentuk dari proses permintaan dan penawaran yang terjadi di bursa. Naik turunnya harga saham yang diperdagangkan di lantai bursa ditentukan oleh kekuatan pasar. Jika pasar menilai bahwa perusahaan penerbit saham dalam kondisi baik, maka biasanya harga saham perusahaan yang bersangkutan akan naik, sedangkan jika 
Khairuriza, et al/Jurnal Ekonomi Syariah Teori dan Terapan Vol. 3 No. 6 Juni 2016: 444-459; ECONOMIC VALUE ADDED DAN MARKET VALUE ADDED SERTA PERILAKU HARGA SAHAM PERUSAHAAN YANG LISTING DI JAKARTA ISLAMIC INDEX (Periode 2010-2014)

perusahaan dinilai rendah oleh pasar, maka harga saham perusahaan juga akan ikut turun bahkan bisa lebih rendah dari harga di pasar sekunder antara investor yang satu dengan investor yang lain sangat menentukan harga saham perusahaan.

Menurut Dwi Dwitayani dikutip dari Rossy (2009), menyatakan bahwa EVA dan MVA merupakan indikator yang mampu menciptakan nilai dari perusahaan. Economic Value Added dan Market Value Added membantu manajer fokus atas penghargaan kepada pemegang saham, yaitu mendapatkan pengendalian modal yang diinvestasikan.

Thenmozhi (2000) mengatakan sebagai berikut:

"Market Value Added can also be defined in relation to Economic Value Added. EVA measures whether the operating profit is enough compared to the total Cost of Capital employed. By increasing EVA, a company increases its Market Value Added or in the other words increases the difference between Company's value and the amount of capital invested. The relationship of MVA with EVA has its implication on valuation."

Dalam kutipan tersebut, Thenmozhi menjelaskan bahwa terdapat dampak pada valuasi saham perusahaan. Dengan meningkatnya EVA, maka sebenarnya perusahaan telah meningkatkan selisih antara nilai perusahaan dan jumlah modal yang diinvestasikan.

Economic Value Added (EVA) dalam penggunaan sebagai alat pengukuran memiliki fungsi untuk mempertimbangkan kemampuan manajer perusahaan dalam menciptakan nilai tambah bagi pemegang saham, sedangkan Market Value Added (MVA) merupakan nilai yang akan diterima investor di pasar modal. (Rossy, 2009)

Besar kecilnya nilai Economic Valve Added (EVA) dan Market Valve Added (MVA) yang diciptakan oleh perusahaan berdampak pada respon investor yang tercermin dari naik turunnya harga saham di pasar modal. Sesuai dengan tujuan perusahaan untuk memaksimalisasi nilai, memerlukan alat ukur kinerja yang nantinya akan menarik para investor untuk menanamkan modalnya di perusahaan tersebut yang dilihat dari meningkatnya harga saham perusahaan ladanya permintaan atas saham perusahaan yang meningkat, sedangkan penawarannya terbatas).

Berdasarkan pendahuluan dan kajian teori yang telah dikemukakan sebelumnya maka dapat diajukan hipotesis sebagai jawaban sementara terhadap masalah adalah sebagai berikut:

1. Economic Value Added (EVA) dan Market Value Added (MVA) secara parsial berpengaruh signifikan terhadap harga saham.

2. Economic Value Added (EVA) dan Market Valve Added (MVA) secara Simultan berpengaruh signifikan terhadap harga saham.

\section{METODE PENELITIAN}

Penelitian ini menggunakan rancangan penelitian berdasarkan pendekatan 
Khairuriza, et al/Jurnal Ekonomi Syariah Teori dan Terapan Vol. 3 No. 6 Juni 2016: 444-459; ECONOMIC VALUE ADDED DAN MARKET VALUE ADDED SERTA PERILAKU HARGA SAHAM PERUSAHAAN YANG LISTING DI JAKARTA ISLAMIC INDEX (Periode 2010-2014)

kuantitatif yang bertujuan untuk menguji kebenaran hipotesis dari suatu rumusan dengan menggunakan analisis statistik, sehingga dapat menghasilkan suatu kesimpulan yang dapat digeneralisasi.

Berdasarkan teknik analisisnya penelitian ini menggunakan asumsi berupa variabel - variabel yang dapat diukur dan berguna untuk mengidentifikasi suatu hubungan (asosiatif) antara dua variabel yaitu variabel bebas dan variabel bergantung serta membandingkan (komparatif) suatu variabel yang sama pada dua sampel yang dimulai dengan hipotesis dan teori - teori.

\section{Identifikasi Data Variabel}

Variabel penelitian adalah sesuatu yang berbentuk apa saja yang ditetapkan dalam penelitian untuk dipelajari (Sugiyono dalam Octavia, 2012:37), sehingga diperoleh informasi tentang hal tersebut, kemudian ditarik kesimpulan. Dari definisi tersebut dapat ditarik kesimpulan bahwa variabel merupakan segala sesuatu yang akan menjadi obyek dalam suatu penelitian. Adapun variabel variabel yang akan diukur dalam penelitian ini adalah sebagai berikut :

1. Variabel bergantung (dependent variabel) yang digunakan dalam penelitian ini yaitu harga saham.

2. Variabel bebas (independent variabel) yang digunakan dalam penelitian ini yaitu:

- Economic Value Added / EVA (X1)

- Market Value Added / MVA (X2)

\section{Definisi Operasional Variabel}

1. Economic Value Added adalah selisih antara adjusted NOPAT (Net Operating After Tax) selama satu tahun buku dikurangi dengan biaya modal (Cost of Capital) dari seluruh modal yang digunakan untuk menghasilkan laba, atau dapat dirumuskan sebagai berikut :

EVA $=$ NOPAT - Capital Charge

2. Market Value Added adalah selisih nilai pasar perusahaan dikurangi nilai buku perusahaan. MVA dihitung dengan rumus :

MVA = Nilai pasar saham - Ekuitas modal yang diberikan pemegang saham

3. Harga saham adalah nilai dari suatu saham yang diperjualbelikan di bursa efek yang diukur dengan nilai mata vang (harga), dimana harga saham tersebut akan ditentukan oleh demand dan supply. Harga saham yang diperjualbelikan di pasar modal dipengaruhi banyak faktor yang akan menimbulkan kenaikan atau penurunan.Data harga saham yang digunakan dalam penelitian ini adalah data harga pembukaan dan penutupan saham pada akhir tahun yang didapat dari yahoofinance.

\section{Populasi dan Sampel}

Populasi adalah wilayah generalisasi yang terdiri atas obyek atau subyek yang 
Khairuriza, et al/Jurnal Ekonomi Syariah Teori dan Terapan Vol. 3 No. 6 Juni 2016: 444-459; ECONOMIC VALUE ADDED DAN MARKET VALUE ADDED SERTA PERILAKU HARGA SAHAM PERUSAHAAN YANG LISTING DI JAKARTA ISLAMIC INDEX (Periode 2010-2014)

mempunyai kualitas dan karekteristik tertentu yang ditetapkan oleh peneliti untuk dipelajari dan kemudian ditarik kesimpulan (Sugiyono,2011:55). Populasi dalam penelitian ini menggunakan perusahaan yang terdaftar di Jakarta Islamic Index selama tahun 2010 - 2014. Yaitu saham-saham perusahaan yang secara pasif tergabung dalam indeks JII dalam kurun waktu tersebut.

Teknik pengambilan sampel dilakukan dengan cara purposive sampling artinya populasi yang akan dijadikan sampel penelitian merupakan populasi yang memiliki kriteria karena tidak semua individu atau elemen dalam populasi mendapat peluang yang sama untuk diambil sebagai sampel. Berikut merupakan kriteria sampel yang akan digunakan oleh peneliti:

1. Perusahaan yang secara konsisten terus menerus tercatat dalam Jakarta Islamic Index selama periode 2010 2014.

2. Perusahaan yang mempublikasikan laporan kevangan (dalam rupiah) secara konsisten serta lengkap dari tahun 2010 - 2014. Data dalam format ini didapat dari situs resmi masingmasing perusahaan yang menjadi sampel serta yang dipublikasikan oleh BEI.

3. Perusahaan tidak sedang delisting selama periode 2010 - 2014.

\section{Jenis dan Sumber Data}

Jenis data yang digunakan dalam penelitian ini untuk dianalisis secara statistik adalah data panel, yang merupakan gabungan dari data runtut waktu (timeseries) dari tahun 2010 hingga tahun 2014

Tabel. 1

Perusahaan yang Menjadi Sampel

\begin{tabular}{|c|l|}
\hline $\begin{array}{c}\text { Kode } \\
\text { Saham }\end{array}$ & \multicolumn{1}{|c|}{ Perusahaan } \\
\hline AALI & Astra Agro Lestari \\
\hline ASII & Astra International \\
\hline ASRI & Alam Sutera Realty \\
\hline CPIN & Charoen Pokphand Indonesia \\
\hline INTP & Indocement Tunggal Prakarsa \\
\hline KLBF & Kalbe Farma \\
\hline LPKR & Lippo Karawaci \\
\hline LSIP & PP London Sumatra Indonesia \\
\hline SMGR & Semen Indonesia (Persero) \\
\hline TLKM & $\begin{array}{l}\text { Telekomunikasi Indonesia } \\
\text { (Persero) }\end{array}$ \\
\hline UNTR & United Tractors \\
\hline UNVR & Unilever Indonesia \\
\hline
\end{tabular}

Sumber : idx.co.id, 2015, data diolah

dengan data silang (cross section) beberapa perusahaan yang memenuhi kriteria sebagai subjek observasi. Sumber data penelitian ini adalah data sekunder. Data sekunder merupakan data yang diperoleh secara tidak langsung. Data didapatkan dengan mengunduh laporan keuangan perusahan tahunan yang dipublikasikan di situs resmi Bursa Efek Indonesia selama periode pengamatan.

\section{Metode Pengumpulan Data}

Prosedur pengumpulan data yang digunakan dalam penelitian ini adalah:

1. Studi kepustakaan, yaitu dengan mengumpulkan literatur yang memiliki hubungan dengan permasalahan yang akan diteliti. 
Khairuriza, et al/Jurnal Ekonomi Syariah Teori dan Terapan Vol. 3 No. 6 Juni 2016: 444-459; ECONOMIC VALUE ADDED DAN MARKET VALUE ADDED SERTA PERILAKU HARGA SAHAM PERUSAHAAN YANG LISTING DI JAKARTA ISLAMIC INDEX (Periode 2010-2014)

2. Penelitian terdahulu, yaitu mengadakan peninjauan dan penelitian secara umum untuk mendapatkan informasi dan mengetahui informasi mengenai permasalahan yang dibahas dalam penelitian.

3. Pengumpulan data sekunder yang diperoleh dari statistik JII yang dipublikasikan melalui situs resmi bursa efek indonesia

\section{Teknik Analisis}

Teknik analisis data yang digunakan adalah teknik analisis regresi linear berganda untuk melihat hubungan antara satu variabel terikat dengan lebih dari satu variabel bebas. Dalam penelitian ini yang akan diteliti adalah bagaimana harga saham (Y) apakah akan dipengaruhi oleh Economic Value Added $\left(X_{1}\right)$ dan Market Value Added $\left(\mathrm{X}_{2}\right)$ Berdasarkan variabel yang digunakan maka hubungan antar variabel dapat dinyatakan dalam fungsi sebagai berikut:

$Y=f\left(X_{1}, X_{2}\right)$

Bentuk persamaan regresi dapat dirumuskan sebagai berikut :

$Y=\beta_{0}+\beta_{1} X_{1}+\beta_{2} X_{2}+e$

\section{Keterangan:}

Y = Harga saham Jakarta Islamic Index

$$
\begin{array}{ll}
\mathrm{X} 1 & =\text { Economic Value Added } \\
\mathrm{X}_{2} & =\text { Market Value Added } \\
\beta_{0} & =\text { Konstanta }
\end{array}
$$

$$
\begin{array}{ll}
\beta_{1} \beta_{2} & =\text { Koefisien Regresi } \\
\mathrm{e} & =\text { Variabel Eror }
\end{array}
$$

\section{Uji Asumsi Klasik Penggunaan Regresi}

Menurut Gujarati (2003:65) terdapat tiga uji statistik yang bisa dilakukan dilakukan untuk mengetahui ada penyimpangan atau tidak dalam suatu regresi yaitu uji multikolinearitas, uji heteroskedastisitas, dan uji autokorelasi. Tujuan dilakukannya uji asumsi klasik ini adalah untuk memastikan bahwa model regresi linier sederhana telah memenuhi asumsi BLUE (Best Linier Unbiased Estimator) sehingga tidak terjadi penelitian yang bias.

\section{Pengujian Regresi Linear Berganda}

1. Uji Parsial (t-test), pengujian ini dilakukan untuk menganalisa pengaruh variabel independen terhadap variabel dependen secara parsial dengan menggunakan derajat kepercayaan sebesar $5 \%$.

2. Uji Simultan (F-test), pengujian ini dilakukan untuk menganalisa pengaruh variabel-variabel independen terhadap variabel dependen secara bersama-sama atau simultan dengan taraf signifikansi $5 \%$.

3. Analisis Koefisien Determinasi $\left(R^{2}\right)$, Koefisien determinasi $\left(\mathrm{R}^{2}\right)$ dimaksudkan untuk mengetahui tingkat ketepatan paling baik dalam menganalisis regresi, dimana hal yang ditunjukkan oleh besarnya koefisien determinasi $\left(R^{2}\right)$ antara nol (0), dan 1 (satu). Koefisien determinasi $\left(R^{2}\right)$ nol, berarti 
Khairuriza, et al/Jurnal Ekonomi Syariah Teori dan Terapan Vol. 3 No. 6 Juni 2016: 444-459; ECONOMIC VALUE ADDED DAN MARKET VALUE ADDED SERTA PERILAKU HARGA SAHAM PERUSAHAAN YANG LISTING DI JAKARTA ISLAMIC INDEX (Periode 2010-2014)

variabel independen sama sekali tidak berpengaruh terhadap variabel dependen. Koefisien determinasi $\left(R^{2}\right)$ dipergunakan untuk mengetahui persentase perubahan variabel tidak bebas (Y) yang disebabkan oleh variabel bebas $(\mathrm{X})$.

\section{HASIL DAN PEMBAHASAN}

Menurut pengujian asumsi klasik yang dilakukan pada variabel-variabel penelitian ini, tidak ditemukan data yang bias. Pada uji heteroskedastisitas, tidak terdapat hubungan antara variabel dependen dengan variabel independen, sehingga bebas dari heteroskedastisitas. Uji multikolinearitas yang dilakukan tidak ada hubungan antara masing-masing variabel, hal ini membuktikan bahwa bebas dari multikolinearitas. Pada Uji Autokorelasi, nilai durbin watson berada di atas -2 dan lebih kecil dari pada 2 sehingga menunjukkan tidak ada korelasi antar variabel. Uji normalitas menunjukkan bahwa variablevariabel dalam penelitian mempunyai distribusi normal.

\section{Tabel 2.}

Hasil Persamaan Regresi

\begin{tabular}{|l|r|r|c|}
\hline \multirow{2}{*}{ Model } & \multicolumn{2}{|c|}{$\begin{array}{c}\text { Unstandardized } \\
\text { Coefficients }\end{array}$} & $\begin{array}{c}\text { Standardized } \\
\text { Coefficients }\end{array}$ \\
\cline { 2 - 4 } & \multicolumn{1}{|c|}{$\mathrm{B}$} & Std. Error & \multicolumn{1}{c|}{ Beta } \\
\hline 1 (Constant & 8224.525 & 1690.631 & \\
) & $-1.112 \mathrm{E}-9$ & .000 & -.730 \\
EVA & $8.985 \mathrm{E}-11$ & .000 & .791 \\
\hline
\end{tabular}

a. Dependent Variable: Harga Saham

Sumber: Hasil Penelitian, 2016, data diolah
Berdasarkan model persamaan yang telah dibahas pada landasan teori dan disesuaikan dengan tabel di atas menunjukkan hasil persamaan regresi, maka dapat disimpulkan sebagai berikut:

$Y=8224.363-1.112 \mathrm{E}-9 X 1+8.985 \mathrm{E}-11 X 2$

Dimana variabel independen adalah harga saham perusahaan JII (Y) sedangkan variabel dependen adalah EVA $\left(X_{1}\right)$ dan MVA $\left(X_{2}\right)$. Dari persamaan regresi linear berganda diatas dapat dijelaskan sebagai berikut:

a. Nilai konstanta sebesar 8224,525 menunjukkan apabila variabel EVA dan MVA besarnya nol atau konstan, maka nilai Harga Saham perusahaan Jll adalah sebesar 8224.525.

b. Koefisien regresi EVA ( $\beta 1)$, Koefisien regresi EVA sebesar $-0,000001112$ memiliki koefisien yang searah dengan Harga Saham perusahaan JII. Setiap kenaikan sebesar satu satuan dari EVA, menyebabkan kenaikan Harga saham sebesar -0,000001112. Begitu pula sebaliknya, setiap penurunan sebesar satu satuan dari EVA, menyebabkan penurunan Harga Saham perusahaan JII sebesar $-0,000001112$ satuan dengan asumsi bahwa variabel yang lain adalah konstan.

c. Koefisien regresi MVA ( $\beta 2$ ), Koefisien regresi MVA sebesar 0,00000008985 memiliki koefisien yang searah dengan Harga Saham perusahaan JII. Setiap kenaikan sebesar satu satuan dari EVA, menyebabkan kenaikan Harga saham 
Khairuriza, et al/Jurnal Ekonomi Syariah Teori dan Terapan Vol. 3 No. 6 Juni 2016: 444-459; ECONOMIC VALUE ADDED DAN MARKET VALUE ADDED SERTA PERILAKU HARGA SAHAM PERUSAHAAN YANG LISTING DI JAKARTA ISLAMIC INDEX (Periode 2010-2014)

sebesar -0,000001112. Begitu pula sebaliknya, setiap penurunan sebesar satu satuan dari MVA, menyebabkan penurunan Harga Saham perusahaan JII sebesar 0,00000008985 satuan dengan asumsi bahwa variabel yang lain adalah konstan.

Dalam penelitian ini variabel EVA memiliki tingkat + hitung sebesar $-3,035$ dengan signifikan sebesar 0,004, maka dari hasil tersebut dapat disimpulkan bahwa nilai signifikansi lebih kecil dari tingkat signifikan yang telah ditentukan yaitu 0,05. Hasil tersebut dapat disimpulkan bahwa EVA berpengaruh signifikan terhadap harga saham perusahaan JII tahun 20102014.

Hal ini menunjukkan bahwa perubahan harga saham sangat dipengaruhi oleh Economic Valve Added (EVA) perusahaan tersebut. Hasil penelitian ini mengidentifikasikan bahwa investor sebelum dalam memutuskan untuk berinvestasi mereka juga memperhatikan nilai EVA yang dihasilkan perusahaan. Bagi investor yang cenderung menggunakan metode analisis fundamental, kinerja keuangan perusahaan tersebut merupakan salah satu faktor utama investor dalam memilih investasi saham. Nilai kinerja kevangan berdasarkan EVA sangat berpengaruh terhadap perilaku investor di pasar modal terhadap demand suatu saham. Besar kecilnya demand tersebut pada akhirnya menyebabkan perubahan harga saham perusahaan JII di pasar modal.

Variabel MVA memiliki tingkat † hitung sebesar 3,291 dengan signifikan sebesar 0,002, maka dari hasil tersebut dapat disimpulkan bahwa nilai signifikansi lebih kecil dari tingkat signifikan yang telah ditentukan yaitu 0,05. Hasil tersebut dapat disimpulkan bahwa MVA berpengaruh signifikan terhadap harga saham perusahaan JII tahun 2010-2014.

Perubahan harga saham oleh pengaruh perubahan MVA mungkin terjadi karena MVA mencerminkan perkiraan besarnya keuntungan pemegang saham atas saham yang dimiliki ketika dijual. Pengukuran kinerja nilai saham menggunakan MVA dapat dijadikan alat untuk memproyeksi jumlah capital gain yang akan diperoleh ketika terjadi transaksi penjualan saham. Oleh sebab itu MVA merupakan persepsi Investor atas kekayaan yang dimilikinya diluar kepemilikan modal yang tertera pada nilai buku saham tersebut.

Tabel 3.

Hasil Uji T

\begin{tabular}{|ll|r|l|}
\hline Model & & \multicolumn{1}{l|}{ Sig. } \\
& & & \\
\hline 1 & (Constant) & 4.865 & \\
& EVA & -3.035 & .000 \\
& MVA & 3.291 & .004 \\
& & .002 \\
\hline
\end{tabular}

a. Dependent Variable: Harga Saham

Sumber: Hasil penelitian, 2016, data diolah

Dari hasil analisis regresi dapat diketahui bahwa secara bersama-sama berpengaruh signifikan terhadap harga saham perusahaan Jll tahun 2010 hingga 
Khairuriza, et al/Jurnal Ekonomi Syariah Teori dan Terapan Vol. 3 No. 6 Juni 2016: 444-459; ECONOMIC VALUE ADDED DAN MARKET VALUE ADDED SERTA PERILAKU HARGA SAHAM PERUSAHAAN YANG LISTING DI JAKARTA ISLAMIC INDEX (Periode 2010-2014)

2014. Dimana nilai untuk $F$ hitung adalah 5,490 dengan signifikansi 0,007 . Sedangkan untuk nilai $F$ tabel dengan signifikansi 0,05 adalah 4,000 dengan penjabaran df untuk pembilang adalah 1 (Jumlah variabel bebas dikurangi variabel terikat) dan df untuk penyebut adalah 59 (jumlah sampel dikurangi df pembilang). Maka hal ini menyimpulkan bahwa $\mathrm{F}$ hitung $>\mathrm{F}$ tabel $(5,490>4,000)$. Dengan tingkat signifikansi yang ditentukan yaitu 0,05 maka dapat disimpulkan bahwa variabel EVA dan MVA secara simultan berpengaruh signifikan terhadap harga saham perusahaan JII tahun 2010 hingga 2014.

Tabel 4.

\section{Hasil Uji F}

\begin{tabular}{|l|l|l|}
\hline & & \\
Model & F & Sig. \\
\hline $\begin{array}{l}\text { Regression } \\
\text { Residual } \\
\text { Total }\end{array}$ & 5.490 & $.007^{\mathrm{a}}$ \\
\hline
\end{tabular}

a. Predictors: (Constant), MVA, EVA

b. Dependent Variable: Harga Saham

Sumber: Hasil Penelitian, 2016, data diolah

Pengaruh kedua variabel (EVA dan MVA) terhadap harga saham berpengaruh sebesar 16,2\%. Hal ini dijelaskan oleh koefisien determinasi $\left(R^{2}\right)$ sebesar 0,162. Artinya EVA dan MVA hanya berpengaruh pada perubahan harga saham sebanyak $16.2 \%$ dari setiap 1 perubahan harga saham, artinya $87,2 \%$ dari faktor yang mempengaruhi harga saham dijelaskan oleh variabel lainnya. Persentase tersebut masih sangat kecil untuk menarik kesimpulan bahwa EVA dan MVA saja sudah cukup untuk digunakan sebagai variabel yang mempengaruhi harga saham.

Tabel 5.

Hasil Koefisien Determinasi $\left(\mathbf{R}^{2}\right)$

\begin{tabular}{|l|r|r|c|}
\hline Model & R Square & \multicolumn{1}{|c|}{$\begin{array}{c}\text { Adjusted R } \\
\text { Square }\end{array}$} & $\begin{array}{c}\text { Std. Error of the } \\
\text { Estimate }\end{array}$ \\
\hline 1 & .162 & .132 & 8970.20266 \\
\hline
\end{tabular}

a. Predictors: (Constant), MVA, EVA

b. Dependent Variable: Harga Saham

Sumber: Hasil Penelitian, 2016, data diolah.

Kecilnya persentase pengaruh EVA dan MVA terhadap saham belum tentu bisa dijelaskan dengan menganalisa variabel kinerja keuangan laiinya. Atau dalam pengertian lain, perubahan harga saham tersebut tidak dapat hanya dijelaskan dengan melakukan analisis fundamental, seperti yang dilakukan dalam penelitian ini, yaitu dengan menganalisa variabel kinerja keuangan dan perusahaan saja. Namun kondisi ekternal perusahan, seperti kondisi keamanan suatu negara, politik, budaya, kondisi keuangan dan perekonomian ikut serta mempengaruhi pergerakan harga saham.

Disamping itu dengan kondisi pasar modal indonesia yang weak form effeciency dan kecenderungan investasi berdasarkan rumor (analisis teknikal) menjadikan variabel kinerja keuangan dan perusahaan tidak cukup akurat jika digunakan untuk mengukur perilaku perubahan harga saham.

\section{SIMPULAN}

Berdasarkan pada hasil analisis dan pembahasan di bab sebelumnya, maka kesimpulan yang didapat di ambil adalah : 
Khairuriza, et al/Jurnal Ekonomi Syariah Teori dan Terapan Vol. 3 No. 6 Juni 2016: 444-459; ECONOMIC VALUE ADDED DAN MARKET VALUE ADDED SERTA PERILAKU HARGA SAHAM PERUSAHAAN YANG LISTING DI JAKARTA ISLAMIC INDEX (Periode 2010-2014)

1. EVA secara parsial berpengaruh secara sigifikan terhadap harga saham perusahaan yang terdaftar di Jakarta Islamic Index (JII) periode 2010- 2014.

2. MVA secara parsial berpengaruh secara signifikan terhadap harga saham perusahaan yang terdaftar di Jakarta Islamic Index (JII) periode 2010 - 2014.

3. Secara simultan, EVA dan MVA berpengaruh signifikan terhadap harga saham yang terdaftar di Jakarta Islamic Index (JII) periode 2010-2014. Sebesar 16,2\% dari setiap 1 perubahan harga saham dapat dijelaskan oleh EVA dan MVA, sedangkan sisanya $87,2 \%$ dijelaskan oleh variabel lain.

Penelitian ini tidak terlepas dari keterbatasan yang meliputi variabel yang digunakan hanya beberapa variabel fundamental eksternal saja, sedangkan masih banyak variabel fundamental lainnya, variabel eksternal dan internal dan faktor-faktor lainnya yang mempengaruhi perubahan harga saham di Jakarta Islamic Index (JII).

Bagi investor yang menanamkan saham pada perusahaan-perusahaan yang terdaftar diJakarta Islamic Indeks (JII) sebaiknya mempertimbangkan keputusan investasinya memperhatikan nilai EVA dan MVA perusahaan terkait, karena terbukti secara statistik bahwa nilai EVA dan MVA berpengaruh secara signifikan. Selain itu, peneliti juga berharap agar motif investasi berdasarkan faktor rumor dalam perdagangan saham secara perlahan ditinggalkan dalam perdagangan saham.

Pengujian dalam penelitian ini hanya terbatas pada dua variabel kinerja kevangan dan periode penelitian selama 2010-2014. Sebaiknya bagi penelitian selanjutnya untuk menambah variabel kinerja kevangan lainnya yang berkaitan dengan pengukuran berbasis nilai seperti CVA (Cash Value Added), SVA (Share Value Added), dan CFROI (Cash Flow Return on Investment) serta menambah periode penelitian. Sehingga hasil penelitian yang terkait kinerja kevangan dengan pengukuran berbasis nilai dapat digeneralisasikan secara lebih akurat untuk seluruh perusahaan di Jll.

\section{DAFTAR PUSTAKA}

Al-Quran

Brigham, E.F \& Houston Joel. 2011. DasarDasar Manajemen Keuangan. Buku 1 Edisi 10. Terjemahan oleh Akbar Yulianto. 2011. Jakarta: Salemba Empat

Gujarati, Damodar. 2003. Ekonometrika Dasar. Edisi Terjemahan. Erlangga: Jakarta

Huda, Nurul dan Mustafa Edwin Nasution. 2008. Investasi Pada Pasar Modal Syariah. Jakarta: Kencana

Huda,Nurul dan Mohamad Heykal. 2010. Lembaga Kevangan Islam Tinjauan Teoritis dan Praktis. Jakarta: Kencana Prenada Media Group 
Khairuriza, et al/Jurnal Ekonomi Syariah Teori dan Terapan Vol. 3 No. 6 Juni 2016: 444-459; ECONOMIC VALUE ADDED DAN MARKET VALUE ADDED SERTA PERILAKU HARGA SAHAM PERUSAHAAN YANG LISTING DI JAKARTA ISLAMIC INDEX (Periode 2010-2014)

Manna, Eka Siswiana. 2011. Pengaruh Economic Value Added Terhadap Harga Saham Perusahaan Go Public di Bursa Efek Indonesia. Thesis. Makassar: Fakultas Ekonomi dan Bisnis Universitas Hasanuddin

O'Byrne, F. Stephen \& S. David Young. 2001. Economic Value Added dan Manajemen Berdasarkan Nilai Panduan Praktis untuk Implementasi. Edisi I Terjemahan oleh Lusy Widjaja. Jakarta: Salemba Empat.

O'Bryne, Stephen F. 1996. EVA and Market Value. Journal of Applied Corporate Finance. Vol.9.no.1. Spring: Bank of America.

Octavia, Dewi Prita Yull. 2012. Pengaruh EVA dan ROA Terhadap Pendapatan Saham Pasar pada Perusahaan yang Tergabung Dalam Jakarta Islamic Index Tahun 2006-2010. Skripsi. Surabaya: Universitas Airlangga

Rahayu, Ury Tri \& Siti Aisjah. 2013. Pengaruh Economic Value Added Dan Market Value Added Terhadap Return Saham. Malang: Universitas Brawijaya

Rossy, Meita. 2009. Analisis Pengaruh

Antara Economic Value Added (EVA) dan Market Value Added (MVA) Terhadap Harga Saham Pada Perusahaan Sektor LQ45 di Bursa Efek Indonesia (BEI) Periode 2007-2008. Jakarta: Fakultas Ekonomi Universitas Gunadharma

Santoso, Singgih. 2000. BukU Latihan SPSS Statistik Non-Parametrik. Jakarta: Elex Media Komputindo
Stewart, G. Bennet.1999. The Economic Value Added: The Quest for Value, A Guide for Senior Managers. : Harper Collins.

Sucipto. 2003. Penilaian Kinerja Keuangan. Medan: Fakultas Ekonomi dan Bisnis Universitas Sumatera Utara

Sugiyono. 2011. Metode Penelitian Kuantitatif Kualitatif dan R\&D. Bandung: Alfabeta.

Suryomurti, Wiku. 2011. Super Cerdas Investasi Syariah. Jakarta. Qultum Media. Thenmozhi, M. 2000. Market Valve Added and Share Behaviour : An Empirical Study Of BSE Sensex Companies. Delhi Business Review, Vol.1. no.1. New Delhi: Satender Kumar Joshi \& Ravinder Goel

Tinneke, Raden., 2007. Analisis Pengaruh Economic Value Added (EVA) dan Faktor-Faktor Fundamental Perusahaan Lainnya Terhadap Return Saham. Tesis. Semarang: Pascasarjana Universitas Diponegoro.

Wahyudi, Muhammad Fajar. 2009. Analisis Kevangan Perusahaan dengan Menggunakan Pendekatan Economic Value Added (EVA) dan Market Value Added (MVA) Periode Tahun 2005-2007 IStudi pada PT. Telekomunikasi Indonesia Tbk.). Skripsi. Malang: Fakultas Ekonomi UIN Malang www.idx.co.id 